\title{
PENINGKATAN TINGKAT KEPUASAN DOSEN TERHADAP KUALITAS PELAYANAN PELATIHAN JURNAL BERKUALITASMELALUI METODE SERVQUAL
}

\author{
Adhy Purnama dan Ilah Sailah \\ Kopertis Wilayah 3 Jl. SMA 14 Cawang, Jakarta Timur \\ e-mail: adhypurnama1982@gmail.com
}

\begin{abstract}
This study aims to provide information on the level of satisfaction of trainees Journal service quality training quality and the most influential factor in the region Ko3f gpertis III. Methods of data collection in this study using the registration documentation (questionnaires), interviews and observations. Data were analyzed using descriptive analysis techniques servqual quantitative analysis method and Cartesian diagrams using SPSS 17. Based on the research results can be obtained gap (the gap value) of tangible dimension, realibility, responsivness, empathy, and assurance sequentially ie $-1.69,-2.12$, - 2:09, -2.04 , and -1.75 . Based on the analysis Cartesian diagram attributes into three main priorities for repair ie friendliness, attention and courtesy of the staff committee and their instructors, clear information about the facility and rules for participants, classroom facilities to support teaching and learning activities.
\end{abstract}

Keywords: customer satisfaction, hope, cartesian diagram, servqual, satisfaction

\begin{abstract}
Abstrak: Penelitian ini bertujuan memberikan informasi tingkat kepuasan peserta pelatihan atas kualitas pelayanan pelatihan Jurnal berkualitas dan faktor yang paling berpengaruh di Kopertis wilayah III.Metode pengumpulan data dalam penelitian ini menggunakan pencatatan dokumentasi (kuisioner), wawancara dan observasi. Data dianalisis menggunakan teknik analisis deskriptif kuantitatif dengan analisis servqual methode dan cartesian diagram menggunakan SPSS 17. Berdasarkan hasil penelitian dapat diperoleh gap (nilai kesenjangan) dari dimensi tangible, realibility, responsivness, empathy, dan assurance secara berurutan yaitu $-1.69,-2.12,-2.09,-2.04$, dan -1.75 . Berdasarkan hasil analisis diagram kartesius atribut yang menjadi tiga prioritas utama untuk diperbaiki yaitukeramahan, perhatian dan kesopanan staf instruktur beserta panitia,informasi yang jelas mengenai fasilitas dan peraturan bagi peserta,fasilitas ruang kelas menunjang kegiatan belajar mengajar.
\end{abstract}

Kata kunci: Kepuasan pelanggan, harapan, diagram kartesius, servqual, tingkat kepuasan

\section{PENDAHULUAN}

Kopertis yang dimulai sejak tahun 1975 peran dan fungsinya sangat nampak berkembang sejalan dengan terbitnya SK Mendikbud No.062/O/1982, No. 0135/ O/1990 dan SK Mendiknas No.184/U/2001, yang menggambarkan Kopertis perpanjangan tangan Ditjen Dikti di wilayah untuk melaksanakan pengawasan, pengendalian dan pembinaan.Terbitnya Undang-undang no. 20 tahun 2003 tentang sistem Pendidikan nasional, dan Higher Education Long Term Strategy 2003 - 2010 bahwa perlu adanya perubahan paradigma peran lembaga pendidikan tinggi yang lebih ditekankan kepada tiga 
strategi dasar yaitu daya saing bangsa, otonomi perguruan tinggi dan organisasi yang sehat (www.kopertis3.or.id). Keberadaan Kopertis pada dewasa ini diperlukan mengingat perkembangan PTS sangat pesat dengan jumlah 2.789 PTS dan tersebar diseluruh wilayah Indonesia sehingga pengawasan pengendalian dan pembinaannya tidak mungkin dilaksanakan langsung oleh Direktorat Jenderal Pendidikan Tinggi.Untuk mencapai tujuan tiga strategi dasar tersebut diatas, Pemerintah dituntut untuk melakukan pengawasan, pengendalian, dan pembinaan pada perguruan tinggi, dengan tidak mengurangi arti otonomi pada perguruan tinggi. Salah satu bentuk pembinaan PTS yaitu mengadakan pelatihan jurnal berkualitas yang diikuti oleh dosen-dosen di wilayah Kopertis III dengan harapan jurnal dari hasil penelitian dapat lolos dalam kriteria jurnal nasional maupun internasional.

Peningkatan kualitas sumber daya manusia khususnya dosen pada Pendidikan tinggi merupakan suatu keharusan. Hal ini dikarenakan pengembangan sumber daya manusia (human resources) dianggap merupakan salah satu solusi dari setiap masalah yang terjadi dalam organisasi/ negara.Pendidikan dan komunikasi yang baik antara para pelaku organisasi mempunyai pengaruh yang sangat penting terhadap kualitas pelayanan (Henryanto,2014). Salah satu pendidikan non formal pada suatu instansi atau organisasi adalah pendidikan dan pelatihan yang sering disebut Diklat. Diklat merupakan bagian dari suatu proses pendidikan yang bertujuan untuk meningkatkan kemampuan atau keterampilan khusus atau sekelompok orang. Diklat dapat juga dipandang sebagai salah satu bentuk investasi. Dalam organisasi atau instansi yang ingin berkembang, diklat bagi pegawai atau karyawan memperoleh perhatian yang sangat besar agar tujuan diklat dapat tercapai sesuai dengan harapan intansi atau organisasi tersebut. Tercapai atau tidaknya tujuan diklat ini juga sangat dipengaruhi oleh kualitas pelayanan yang diberikan oleh penyelenggara diklat itu sendiri.

Permasalahan yang terjadi dalam mengukur keberhasilan suatu kegiatan pelatihan, diklat ataupun bimbingan teknis adalah tidak adanya wadah dalam menampung keluhan peserta dalam bentuk kuisioner. Apabila hal ini dibiarkan maka akan berdampak pada sulitnya manajemen melakukan evaluasi pelayanan terhadap para pelanggan/konsumen. Jika proses evaluasi pelayanan sulit untuk dilakukan, maka akan berpengaruh terhadap menurunnya pelayanan kepada pelanggan (PTS) yang menghadiri undangan(Dewa at al., 2014). Evaluasi pada pelatihan di Kopertis Wilayah III belum pernah dilaksanakan dengan sistematis. Kopertis Wilayah III hanya telah melaksanakan evaluasi terhadap peserta pelatihannya saja dan belum menyentuh aspek lebih detail seperti materi pelatihan, sarana prasarana, pelatih,dll. Evaluasi pelatihan menjadi sangat penting untuk dipelajari karena evalusi akan mengukur tingkat ketercapaian dari program pelatihan yang dilakukan sehingga akan memberikan feed back untuk kelangsungan program pelatihanselanjutnya. Selain peserta yang menjadi ujung tombak keberhasilan atau ketercapaian program pelatihan adalah instruktur yang memberikan materi pelatihan.Maka, evaluasi pelaksanaan pelatihan sangat perlu dilaksanakan untuk mengetahui tingkat ketercapaian dari program pelatihan yang diselenggarakan (Satriawan et al., 2016).

Tujuan dari penelitian ini adalah mengetahui tingkat kepuasan pelanggan terhadap kualitas pelayanan dan mengetahui atribut-atribut pelayanan yang diprioritaskan untuk diperbaiki dan dipertahankanagar Kopertis Wilayah III khususnya bagian Akademik dan 
kemahasiswaan dapat memaksimalkan kualitas pelayanannya guna meningkatkan mutu dosen perguruan tinggi swasta di wilayah Kopertis III.

\section{KAJIAN TEORI}

Kualitas jasa sebagai ukuran seberapa bagus tingkat pelayanan yang diberikan mampu sesuai dengan ekspektasi pelanggan. Berdasarkan definisi ini, kualitas jasa dapat diwujudkan melalui pemenuhan kebutuhan dan keinginan pelanggan serta ketepatan penyampaiannya untuk mengimbangi harapan pelanggan (Tjiptono, 2005)sesuai dengan ekspektasi pelanggan. Zeithaml, Berry dan Parasuraman (1985) telah melakukan berbagai penelitian terhadap beberapa jenis jasa, dan berhasil mengidentifikasi lima dimensi karakteristik yang digunakan oleh para pelanggan dalam mengevaluasi kualitas pelayanan. Menurut Zulian (2002) kelima dimensi karakteristik kualitas pelayanan tersebut adalah: 1.Tangibles(Nyata) yaitu meliputi penampilan fisik, perlengkapan, pegawai, dan sarana komunikasi. 2.Reliability (Keandalan) yaitu kemampuan memberikan pelayanan yang dijanjikan dengan segera, akurat, dan memuaskan. 3.Responsiveness (Daya Tanggap) yaitu keinginan para staf untuk membentuk para pelanggan dan memberikan pelayanan dengan tanggap. 4.Assurance (Jaminan) mencakup pengetahuan, kemampuan, kesopanan, dan sifat dapat dipercaya yang dimiliki para staf bebas dari bahaya, resiko atau keragu-raguan. 5.Emphaty(Empati) meliputi kemudahan dalam melakukan hubungan, komunikasi yang baik, perhatian pribadi, dan memahami kebutuhan pelanggan.

MetodeService QualityServqual merupakan suatu carainstrument untuk melakukan pengukuran kualitas jasa yang dikembangkan oleh Parasuraman, Zeithaml dan Berry dalam serangkaian penelitian mereka terhadap sektor-sektor jasa, model ini juga dikenal dengan istilahGap. Model ini berkaitan erat dengan model kepuasan. Dalam modelServqual, kualitas jasadidefinisikan sebagai penilaian atau sikapglobal berkenaan dengan superioritas suatu jasa (Parasuramanet al.,1985). Definisi pada tiga landasan konseptual utama, yakni:1.Kualitas jasa lebih sukar dievaluasi konsumen daripada kualitas barang. 2.Persepsi terhadap kualitas jasa merupakan hasil dari perbandingan antara harapan pelanggan dengan kinerja aktual jasa. 3.Evaluasi kualitas tidak hanya dilakukan atas hasil jasa, tetapi juga mencakup evaluasi terhadap proses penyampaian jasa.

\section{METODE}

Penelitian ini dilakukan di Kopertis Wilayah III, Jl. SMA 14 Cawang Daerah Khusus Ibukota Jakarta. Batasan masalah dalam penelitian ini adalah sebagai berikut: 1 . Variabel yang digunakan dalam penelitian ini adalah variable kualitas pelayanan yang meliputi responsiveness (daya tanggap), reliability (keandalan), assurance (jaminan), emphaty (empati), tangibles (bukti langsung). 2. Gap yang digunakan pada penelitian ini adalah kesenjangan antara jasa yang dipersepsikan dengan jasa yang diharapkan (service gap). Populasi pada penelitian ini adalah Dosen Perguruan tinggi swasta di lingkungan Kopertis Wilayah III. Kriteria responden yang dipilih yaitu yang mengikuti pelatihan jurnal berkualitas pada tahun 2017. Pada penelitian ini menggunakan dua tahapan pengambilan sampel yaitu yang pertama menggunakan pengambilan sampel pendahuluan 
sebanyak 30. Pengambilan sampel yang kedua yaitu pengambilan sampel minimal. Berdasarkan Slovin dengan menentukan besarnya sampel dengan rumus sebagai berikut:

$$
\mathrm{n}=\frac{N}{1+N(\boldsymbol{e})^{2}}
$$

dimana : $\mathrm{n}=$ Ukuran Sampel; $\mathrm{N}=$ Populasi (130 Orang); e = \% kelonggaran ketidaktelitian karena kesalahan

$$
\begin{aligned}
& \mathrm{n}=\frac{130}{1+130(5 \%)^{2}} \\
& \mathrm{n}=98 \text { Orang }
\end{aligned}
$$

Dalam penelitian ini ukuran sampel dibulatkan menjadi 100 orang responden (dari 130 orang populasi), dimana jumlah tersebut sudah diatas jumlah minimal responden berdasarkanperhitungan diatas. Besaran sampel yang layak pada penelitian adalah 30 sampai dengan 500(Sugiyono,2012), sedangkan menurutasnawi dan Masyuri (2011) mengatakan besaran sampel minimum untuk penelitian adalah sebanyak 100. Penyusunan kuesioner disusun berdasarkan metode Servqual. Kuesioner ini terdiri dari beberapa pertanyaan yang dibagi dalam beberapa bagian, yaitu: 1. Pertanyaan mengenai identitas responden. Pertanyaan ini digunakan untuk mengumpulkan data tentang responden yang meliputi jenis kelamin, usia, pendidikan terakhir, pekerjaan, dan lainlain. 2. Pertanyaan mengenai identifikasi persepsi dan harapan peserta. Pertanyaan ini mengukur persepsi dan harapan peserta terhadap kualitas pelayanan yang berisi pertanyaan-pertanyaan yang mewakili kelima variabel dalam kualitas pelayanan. Penilaian dilakukan oleh responden dengan menggunakan skala likert satu sampai lima untuk setiap pertanyaan. 3. Pertanyaan yang mengukur tingkat kepentingan dari setiap variabel. Responden memberikan nilai sesuai dengan tingkat kepentingan setiap variabel sehingga didapatkan jumlah nilai keseluruhan dari masing-masing variabel mencapai 100 .

Uji validitas maupun reliabilitas tidak diujikan kepada seluruh responden ketika proses pengambilan data selesai, tetapi diujikan kepada sampel pendahuluan sebanyak minimal 30 orang responden. Hal ini dilakukan karena jika ada item yang tidak valid atau variabel yang tidak reliabel, maka masih punya kesempatan untuk memperbaiki instrumen tersebut (Suliyanto, 2012). Penelitian yang memiliki sebuah instrumen bisa dikatakan valid adalah apabila penelitian tersebut mampu mengukur apa yang diinginkan. Pada penelitian ini taraf signifikan atau relevan kepercayaan yang digunakan adalah $95 \%$. Teknik yang dipakai untuk menguji validitas kuesioner ini digunakan rumus teknik korelasi product moment sebagai berikut.

$$
\mathrm{r}_{\mathrm{xy}} \frac{n \Sigma X Y-\Sigma X \Sigma Y}{\sqrt{n \Sigma x^{2}-(\Sigma X)^{2}} \sqrt{n \Sigma Y^{2}-(\Sigma Y)^{2}}}
$$

Dimana: $\mathrm{r}_{\mathrm{xy}}=$ Korelasi antara $\mathrm{X}$ dan $\mathrm{Y} ; \mathrm{n}=$ Jumlah responden; $\mathrm{X}=$ Skor masing-masing pertanyaan; $\mathrm{Y}=$ Skor total , Kriteria Uji jika rhitung > rtabel maka data dinyatakan valid.

Selanjutnya dilakukan uji reabilitas (keandalan). Reabilitas adalah suatu nilai yang menunjukkan konsistensi suatu alat ukur di dalam mengukur gejala yang sama.Reabilitas 
alat ukur dalam bentuk skala dapat dicari dengan menggunakan teknik cronbach's alpha $(\alpha)$ dapat dilihat sebagai berikut :

$$
\mathrm{r} 11=\left(\frac{k}{k-1}\right)\left(1-\frac{\Sigma \sigma^{2}}{\sigma_{t}^{2}}\right)
$$

Keterangan: $\mathrm{r} 11=$ Reliabilitas instrumen; $\mathrm{k}=$ Banyak butir pertanyaan; $\sigma \mathrm{t}^{2}=$ Varian total $\sigma^{2}=$ Jumlah varian butir pertanyaan. Untuk mengetahui jumlah varian butir pertanyaan menggunakan rumus:

$$
\sigma^{2}=\frac{\Sigma x^{2}-\frac{(\Sigma X)^{2}}{n}}{n}
$$

Keterangan: $\mathrm{n}=$ Jumlah sampel; $\sigma=$ Jumlah varian; $\mathrm{x}=$ Nilai skor yang dipilih (total dari butir pertanyaan)

Analisis data untuk mengetahui kualitas pelayanan di Kopertis Wilayah III, dilakukan dengan menggunakan metode servqual. Ada dua langkah dalam penerapan metode servqual yaitu:

1. Menghitung kesenjangan yang terjadi antara harapan peserta mengenai pelayanan jasa terhadap kenyataan pelayanan yang dirasakan oeh peserta dari lima dimensi Parasuraman's Servqual Model yang meliputi dimensi tangible, Relibility, Responsivness, Assurance, dan Empathy. (a) Menentukan Frekwensi jawaban responden terhadap variabel peryataan kualitas pelayanan; (b) Menentukan jumlah bobot jawaban untuk kenyatan pelayanan yang dirasakan oleh peserta; (c) Untuk menghitung kenyataan pelayanan yang dirasakan peserta

$$
\sum \mathrm{x}_{\mathrm{i}}=\left(\sum \mathrm{STP} \times 1\right)+\left(\sum \mathrm{TP} \times 2\right)+\left(\sum \mathrm{CP} \times 3\right)+\left(\sum \mathrm{P} \times 4\right)+\left(\sum \mathrm{SP} \times 5\right)
$$

Dimana: $\sum \mathrm{x}_{\mathrm{i}}=$ Jumlah Bobot jawaban variabel ke $\mathrm{i}$; STP $=$ Jumlah orang yang memilih jawaban sangat tidak puas; $\mathrm{TP}=$ Jumlah orang yang memilih jawaban tidak puas; $\mathrm{CP}=$ Jumlah orang yang memilih jawaban cukup puas; $\mathrm{P}=$ Jumlah orang yang memilih jawaban puas; $\mathrm{SP}=$ Jumlah orang yang memilih jawaban sangat puas; $1,2,3,4,5=$ Skor untuk skala linkert.

(c) Menghitung rata-rata Jawaban persepsi Respondenmenggunakan persamaan berikut

$$
\bar{X}=\frac{\Sigma X i}{n}
$$

Dimana: $\bar{X}=$ Rata-rata Jawaban Responden Variabek ke $-\mathrm{i}$; $\Sigma x i=$ Jumlah Bobot Variabel ke $-\mathrm{i} ; \mathrm{n}=$ Jumlah Responden

(d) Menghitung harapan peserta mengenai pelayanan jasa

$$
\sum \mathrm{y}_{\mathrm{i}}=\left(\sum \mathrm{STP} \times 1\right)+\left(\sum \mathrm{TP} \times 2\right)+\left(\sum \mathrm{CP} \times 3\right)+\left(\sum \mathrm{P} \times 4\right)+\left(\sum \mathrm{SP} \times 5\right)
$$

Dimana: $\sum \mathrm{y}_{\mathrm{i}}=$ Jumlah Bobot jawaban variabel ke i; STP = Jumlah orang yang memilih jawaban sangat tidak Puas; TP = Jumlah orang yang memilih jawaban Tidak Puas; $\mathrm{CP}=$ Jumlah orang yang memilih jawaban Cukup Puas; $\mathrm{P}=$ Jumlah orang yang memilih jawaban Puas; $\mathrm{SP}=$ Jumlah orang yang memilih jawaban sangat Puas; 1,2,3,4,5 = Skor untuk skala linkert 
(e) Menghitung rata-rata Jawaban Harapan Responden menggunakan persamaan berikut

$$
\bar{Y}=\frac{\Sigma Y i}{n}
$$

Dimana: $\bar{Y}=$ Rata-rata Jawaban Responden Variabel ke $-\mathrm{i} ; \quad$ yi $=$ Jumlah Bobot Variabel ke -i; $\mathrm{n}=$ Jumlah Responden.

(f) Menghitung nilai gap (kesenjangan antara harapan dan kenyataan peserta), digunakan persamaan berikut:

$$
\mathrm{SQI}=\overline{X_{l}}-\overline{Y_{l}}
$$

Dimana: SQi $=$ Nilai gap variabel ke i; $\bar{X} l=$ Nilai rata kenyataan variabel ke i; $\bar{Y}_{l}=$ Nilai rata-rata harapan variabel ke $\mathrm{i}$

(g) Mengitung rata-rata jawaban perdimensi nilai gap untuk kenyataan

$$
\bar{X} D i=\frac{\Sigma X V i}{n}
$$

Dimana: $\bar{X} D i=$ Rata - rata dimensi variabel ke $\mathrm{i} ; \Sigma X V i=$ Jumlah nilai rata-rata variabel peryataan perdimensi ke $\mathrm{i} ; \mathrm{n}=$ Jumlah peryataan perdimensi

(h) Mengitung rata-rata jawaban perdimensi nilai gap untuk harapan

(i)

$$
\bar{Y} D i=\frac{F r r_{i}}{m}
$$

Dimana: $\bar{Y} D i=$ Rata - rata dimensi variabel ke i; $\Sigma Y V i=$ Jumalh nilai rata-rata variabel peryataan perdimensi ke $\mathrm{i} ; \mathrm{n}=$ Jumlah peryataan perdimensi

2. Membuat Diagram Kartesius sebagai jawaban untuk meenentukan variabel-variabel mana yang paling berpengaruh terhadap kualitas pelayanan yang diberikan oleh Kopertis Wilayah III terhadap peserta terlihat pada Gambar 1.

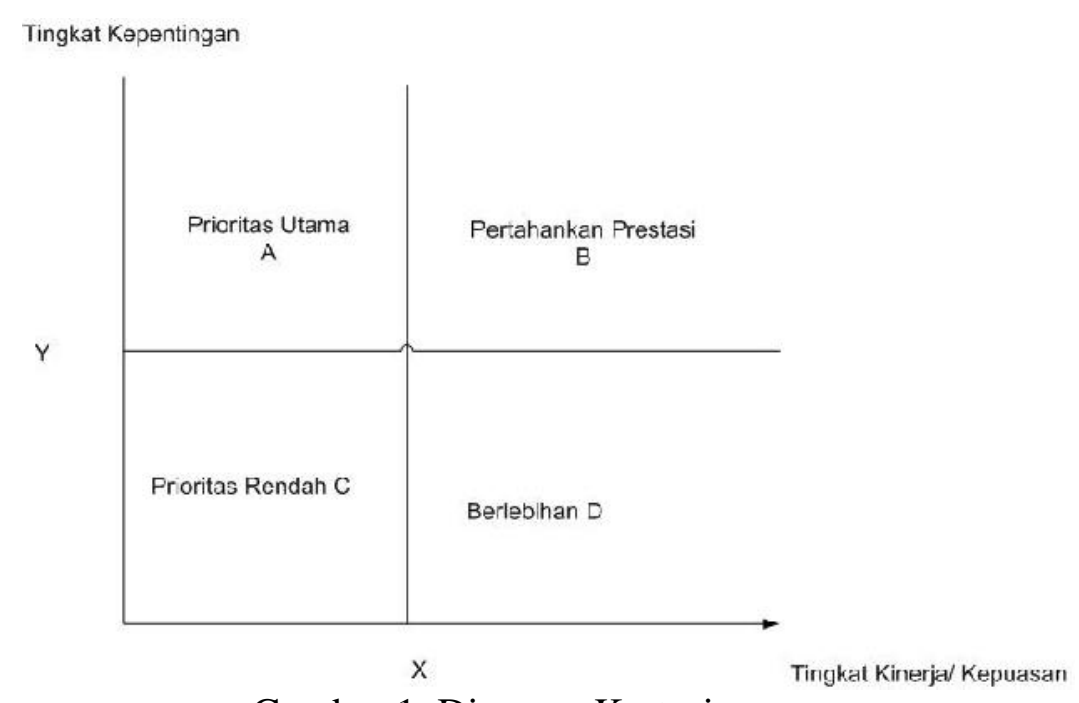

Gambar 1. Diagram Kartesisus 
Variabel yang masuk kuadran 1 mempunyai pengaruh tinggi namun performansinya belum memuaskan, varabel-variabel dalam kuadran II mempunyai tingkat kepentingan tinggi dengan performansi yang juga memuaskan sehingga penyedia jasa harus memperbaiki kualitas pelayanan, Variabel-variabel dalam kuadran III mempunyai tingkat kepentingan yang rendah dengan performansi yang belum memuaskan sehingga mempunyai prioritas rendah untuk usaha perbaikan dan peningkatan kualitas pelayana. Variabel-variabel dalam kuadran IV mempunyai tingkat kepentingan yang rendah dengan performansi yang sudah cukup memuaskan, sehingga yang dapat dilakukan adalah pengulangan penekanan usaha perbaikan dan peningkatan kualitas pelayanan.

Diagram kartesius adalah alat untukmenentukan prioritas dengan memetakan nilai rata-rata (Supranto, 2006). Dalam pengolahan diagram kartesius ini yaitu dengan memasukkan rata-rata dari variabel $\mathrm{y}$, dan rata-rata dari variabel kenyataan yang dirasakan peserta sebagai variabel x kedalam diagram. Dalam penelitian ini terdapat 20 item variabel yang akan mempengaruhi kepuasan peserta yang akan terbagi ke dalam 4 kuadran, untuk mendapatkan sumbu $\mathrm{X}$ dan sumbu $\mathrm{Y}$ dalam diagram kartesius yang menjadi batasan rata-rata pertanyaan sumbu $\overline{\bar{X}}$ sebagai kenyataan pelayanan dan sumbu $\overline{\bar{Y}}$ sebagai harapan terhadap pelayanan dengan menggunakan rumus sebagai berikut:

$$
\overline{\bar{X}}=\frac{\sum_{i-1}^{n} \overline{X i}}{n} \overline{\bar{Y}}=\frac{\sum_{i-1}^{n} \overline{Y_{l}}}{n}
$$

$\overline{\bar{X}}=$ Rata-rata nilai kuadran mengenai kenyataan yang dirasakan peserta $; \overline{\bar{Y}}=$ rata-rata nilai kuadran mengenai harapan peserta; $\sum_{i-1}^{n} \overline{X l}=$ jumlah rata-rata nilai kenyataan yang dirasakan peserta; $\sum_{i-1}^{n} \overline{Y_{\iota}}=$ Jumlah rata-rata nilai harapan peserta; $\mathrm{K}=$ jumlah variabel peryataan.

\section{HASIL DAN PEMBAHASAN}

Gambaran umum responden diperoleh dari data kuesioner yang telah diisi pengunjung. Gambaran umum ini dapat memberikan informasi mengenai informasi demografis dari Dosen di Kopertis Wilayah III. Berdasarkan hasil kuesioner 100 responden diperoleh data demografis Dosen yang mengikuti pelatihan jurnal berkualitas di Kopertis Wilayah III yang ditunjukkan pada Tabel 1.

Tabel 1. Identifikasi Responden

\begin{tabular}{ccccc}
\hline No & $\begin{array}{c}\text { Karakteristik } \\
\text { Responden }\end{array}$ & Kelompok & Jumlah & $\%$ \\
\hline \multirow{3}{*}{1} & & $25-35$ & 42 & 0.42 \\
& Usia & $36-45$ & 43 & 0.43 \\
& & $46-55$ & 13 & 0.13 \\
\multirow{2}{*}{2} & & $>/ 55$ & 2 & 0.02 \\
& \multirow{3}{*}{ Jenis Kelamin } & Laki-laki & 63 & 0.63 \\
& & Perempuan & 37 & 0.37 \\
\hline
\end{tabular}




\begin{tabular}{lcccc}
\hline \multirow{3}{*}{3} & Pendidikan & S1 & 25 & 0.25 \\
& & S2 & 69 & 0.69 \\
& & S3 & 6 & 0.06 \\
\multirow{3}{*}{4} & Universitas & 23 & 0.23 \\
& \multirow{2}{*}{ Tempat Mengajar } & Sekolah Tinggi & 45 & 0.45 \\
& & Politeknik & 32 & 0.32 \\
\hline
\end{tabular}

Pengujian validitas dimaksudkan untuk mengetahui tingkat keandalan dan kesahihan alat ukur yang digunakan. Instrumen dikatakan valid berarti menunjukkan alat ukur yang dipergunakan untuk mendapatkan data itu valid atau dapat digunakan untuk mengukur apa yang seharusnya di ukur (Sugiyono, 2004). Data hasil pengujian validitas dengan menggunakan softwareSPSS 17ini dapat dilihat pada Tabel 2.

Tabel 2. Data Hasil Uji Validitas Seluruh Responden

\begin{tabular}{|c|c|c|c|c|c|c|}
\hline Dimensi & No & Kriteria & $\begin{array}{l}\text { Tingkat } \\
\text { Harapan }\end{array}$ & $\begin{array}{l}\text { Tingkat } \\
\text { Persepsi }\end{array}$ & r Tabel & Hasil \\
\hline \multirow[t]{4}{*}{ Kesigapan } & 1 & $\begin{array}{l}\text { Kemudahan } \\
\text { menghubungi } \\
\text { Panita Pelatihan } \\
\text { mengenai } \\
\text { informasi } \\
\text { pelatihan }\end{array}$ & 0.452 & 0.431 & 0.349 & valid \\
\hline & 2 & $\begin{array}{l}\text { Keramahan, } \\
\text { perhatian dan } \\
\text { kesopanan staf } \\
\text { instruktur beserta } \\
\text { karyawan }\end{array}$ & 0.481 & 0.438 & 0.349 & valid \\
\hline & 3 & $\begin{array}{l}\text { Instruktur disiplin } \\
\text { dan bertanggung } \\
\text { jawab terhadap } \\
\text { pelatihan, } \\
\text { kecepatan dalam } \\
\text { nenangangani } \\
\text { keluhan pesera }\end{array}$ & 0.487 & 0.396 & 0.349 & valid \\
\hline & 4 & $\begin{array}{l}\text { Informasi adanya } \\
\text { pelatihan } \\
\text { diberikan (1 } \\
\text { minggu/ kurang } 5 \\
\text { hari/ kurang } 2 \\
\text { hari) }\end{array}$ & 0.480 & 0.527 & 0.349 & valid \\
\hline Empathy & 5 & $\begin{array}{l}\text { Kemampuan staf } \\
\text { instruktur } \\
\text { berkomunikasi } \\
\text { dengan peserta }\end{array}$ & 0.526 & 0.546 & 0.349 & valid \\
\hline
\end{tabular}




\begin{tabular}{|c|c|c|c|c|c|c|}
\hline Dimensi & No & Kriteria & $\begin{array}{l}\text { Tingkat } \\
\text { Harapan }\end{array}$ & $\begin{array}{l}\text { Tingkat } \\
\text { Persepsi }\end{array}$ & r Tabel & Hasil \\
\hline & 6 & $\begin{array}{l}\text { Informasi yang } \\
\text { jelas mengenai } \\
\text { jadwal } \\
\text { pelaksanaan } \\
\text { pelatihan }\end{array}$ & 0.650 & 0.479 & 0.349 & valid \\
\hline & 7 & $\begin{array}{l}\text { Informasi yang } \\
\text { jelas menegenai } \\
\text { fasilitas dan } \\
\text { peraturan bagi } \\
\text { peserta }\end{array}$ & 0.631 & 0.408 & 0.349 & valid \\
\hline \multirow[t]{5}{*}{ Bukti Fisik } & 8 & $\begin{array}{l}\text { Fisik tampilan } \\
\text { gedung pelatihan } \\
\text { baik }\end{array}$ & 0.526 & 0.737 & 0.349 & valid \\
\hline & 9 & $\begin{array}{l}\text { Fasilitas ruang } \\
\text { kelas menunjang } \\
\text { kegiatan belajar } \\
\text { mengajar }\end{array}$ & 0.597 & 0.462 & 0.349 & valid \\
\hline & 10 & $\begin{array}{l}\text { Toilet bersih dan } \\
\text { lengkap (tissue, } \\
\text { dll) }\end{array}$ & 0.474 & 0.423 & 0.349 & valid \\
\hline & 11 & $\begin{array}{l}\text { Snack dan } \\
\text { makanan } \\
\text { berkualitas }\end{array}$ & 0.704 & 0.924 & 0.349 & valid \\
\hline & 12 & $\begin{array}{l}\text { Instruktur dan } \\
\text { karyawan selalu } \\
\text { berpakaian rapi } \\
\text { dan sopan }\end{array}$ & 0.590 & 0.548 & 0.349 & valid \\
\hline \multirow[t]{5}{*}{ Kehandalan } & 13 & $\begin{array}{l}\text { Pelatihan diadakan } \\
\text { tepat waktu }\end{array}$ & 0.618 & 0.379 & 0.349 & valid \\
\hline & 14 & $\begin{array}{l}\text { Rangkaian materi } \\
\text { yang diberikan } \\
\text { bermutu sesuai } \\
\text { dengan sasaran } \\
\text { program }\end{array}$ & 0.692 & 0.476 & 0.349 & valid \\
\hline & 15 & $\begin{array}{l}\text { Instruktur } \\
\text { menguasai materi } \\
\text { pelatihan dan } \\
\text { menguasai situasi } \\
\text { selama pelatihan }\end{array}$ & 0.795 & 0.924 & 0.349 & valid \\
\hline & 16 & $\begin{array}{l}\text { Metode belajar } \\
\text { (diskusi, role play, } \\
\text { dll) membantu } \\
\text { dalam mencapai } \\
\text { sasaran pelatihan }\end{array}$ & 0.385 & 0.540 & 0.349 & valid \\
\hline & 17 & $\begin{array}{l}\text { Pre-test dapat } \\
\text { memacu semnagat } \\
\text { belajar dan }\end{array}$ & 0.734 & 0.602 & 0.349 & valid \\
\hline
\end{tabular}




\begin{tabular}{|c|c|c|c|c|c|c|}
\hline Dimensi & No & Kriteria & $\begin{array}{c}\text { Tingkat } \\
\text { Harapan }\end{array}$ & $\begin{array}{l}\text { Tingkat } \\
\text { Persepsi }\end{array}$ & r Tabel & Hasil \\
\hline \multirow{4}{*}{ Jaminan } & & $\begin{array}{l}\text { kesiapan dalam } \\
\text { mengikuti } \\
\text { pelatihan }\end{array}$ & & & & \\
\hline & 18 & $\begin{array}{l}\text { Handout yang } \\
\text { diberikan } \\
\text { membantu dalam } \\
\text { pemahaman } \\
\text { materi }\end{array}$ & 0.666 & 0.420 & 0.349 & valid \\
\hline & 19 & $\begin{array}{l}\text { Peserta bisa } \\
\text { mendapatkan } \\
\text { pelatihan ulang } \\
\text { jika peserta } \\
\text { memburtuhkan } \\
\text { lagi }\end{array}$ & 0.408 & 0.419 & 0.349 & valid \\
\hline & 20 & $\begin{array}{l}\text { Peserta bisa } \\
\text { menanyakan } \\
\text { materi pelatihan } \\
\text { setelah proses } \\
\text { pelatihan selesai }\end{array}$ & 0.395 & 0.405 & 0.349 & valid \\
\hline
\end{tabular}

Nilai $\mathrm{r}$ hitung dari 30 responden tersebut dengan taraf kepercayaan 95\% sebesar 0.349. Berdasarkan hasil uji validitas yang digunakan pada seluruh responden menyatakan bahwa keseluruhan atribut memenuhi syarat atau valid karena mempunya nilai $r$ tabel di atas 0.349 .

Uji reliabilitas digunakan untuk menguji data sehingga hasil dari pengujian tersebut dapat memastikan data yang didapatkan dari hasil penelitian telah reliable (dapat dipercaya). Sekaran(2006)menyatakan bahwa suatu instrumen penelitian mengindikasikan memiliki reliabilitas yang memadai jika koefisien alpha cronbach lebih besar atau sama dengan 0.70. Uji reliabilitas pada 100 sampel responden menyatakan bahwa 20 atribut yang digunakan untuk pengujian tingkat persepsi dan harapan dinyatakan reliable karena menunjukkan koefisien alpha cronbachyang didapat $>0.70$. Data hasil pengujian reliabilitas ini dapat dilihat pada Tabel 3.

Tabel 3. Koefisien Reabilitas Gap

\begin{tabular}{lcc}
\hline & cronbach alpha & Reliabilitas \\
\hline Harapan Konsumen & 0.855 & reliable \\
Kenyataan Pelayanan & 0.877 & reliable \\
\hline
\end{tabular}

Pengolahan data selanjutnya yaitu menghitung gap yaitu harapan peserta mengenai pelayanan jasa terhadap kenyataan pelayanan yang dirasakan peserta. Diawali dengan perhitungan jawaban peryataan pelayanan jasa dikumpulkan dari 100 responden dilihat dari Tabel 4. 
Tabel 4. Frekwensi jawaban responden terhadap variabel kualitas pelayanan

\begin{tabular}{|c|c|c|c|c|c|c|c|c|c|c|}
\hline \multirow{2}{*}{$\begin{array}{c}\text { Varibel } \\
\text { Pertanyaan }\end{array}$} & \multicolumn{5}{|c|}{ Tingkat Harapan Pelayanan } & \multicolumn{5}{|c|}{ Tingkat Persepsi Pelayanan } \\
\hline & STP & $\mathrm{TP}$ & $\mathrm{CP}$ & $\mathrm{P}$ & SP & STP & $\mathrm{TP}$ & $\mathrm{CP}$ & $\mathrm{P}$ & SP \\
\hline $\mathrm{P} 1$ & & & & 50 & 42 & 4 & 10 & 43 & 5 & \\
\hline $\mathrm{P} 2$ & & & & 50 & 41 & 4 & 9 & 42 & 5 & \\
\hline P3 & & & & 49 & 41 & 4 & 9 & 41 & 5 & \\
\hline P4 & & & & 49 & 40 & 4 & 8 & 41 & 5 & \\
\hline P5 & & & & 49 & 39 & 4 & 8 & 40 & 5 & \\
\hline P6 & & & & 49 & 39 & 4 & 8 & 40 & 5 & \\
\hline P7 & & & & 49 & 38 & 4 & 8 & 40 & 5 & \\
\hline P8 & & & & 49 & 37 & 4 & 7 & 38 & 5 & \\
\hline P9 & & & & 49 & 36 & 4 & 6 & 38 & 5 & \\
\hline P10 & & & & 48 & 36 & 4 & 6 & 37 & 5 & \\
\hline P11 & & & & 48 & 35 & 4 & 6 & 37 & 5 & \\
\hline $\mathrm{P} 12$ & & & & 48 & 34 & 4 & 6 & 36 & 5 & \\
\hline P13 & & & & 47 & 33 & 3 & 5 & 35 & 5 & \\
\hline P14 & & & & 47 & 33 & 3 & 5 & 34 & 5 & \\
\hline P15 & & & & 47 & 33 & 3 & 5 & 33 & 5 & \\
\hline P16 & & & & 46 & 32 & 3 & 5 & 32 & 5 & \\
\hline P17 & & & & 46 & 32 & 3 & 5 & 31 & 5 & \\
\hline P18 & & & & 43 & 28 & 3 & 4 & 27 & 5 & \\
\hline P19 & & & & 43 & 27 & 3 & 4 & 27 & 5 & \\
\hline $\mathrm{P} 20$ & & & & 43 & 26 & 3 & 4 & 27 & 5 & \\
\hline
\end{tabular}

Keterangan : STP: sangat tidak puas, TP: tidak puas, CP: cukup puas, P: puas, SP: sangat puas

Berikut ini merupakan nilai rata-rata harapan peserta mengenai pelayanan jasa terhadap kenyataan pelayanan yang dirasakan oleh peserta terhadap variabel pernyataan kualitas pelayanan dilihat pada Tabel 5 .

Tabel 5. Nilai Rata-Rata Gap Terhadap Variabel Kualitas Pelayanan

\begin{tabular}{|c|c|c|c|c|c|c|c|}
\hline \multirow{2}{*}{$\begin{array}{l}\text { variabel } \\
\text { Pertanyaan }\end{array}$} & \multicolumn{2}{|c|}{$\begin{array}{c}\text { Tingkat Kepentingan } \\
\text { Harapan }\end{array}$} & \multicolumn{2}{|c|}{$\begin{array}{c}\text { Tingkat Kepentingan } \\
\text { Persepsi }\end{array}$} & \multirow{2}{*}{$\begin{array}{l}\text { Nilai } \\
\text { Gap }\end{array}$} & \multirow{2}{*}{$\begin{array}{c}\text { Jumalah } \\
\text { rata-rata } \\
\text { perdimensi } \\
\text { Harapan }\end{array}$} & \multirow{2}{*}{$\begin{array}{c}\text { Jumalah } \\
\text { rata-rata } \\
\text { perdimens } \\
\text { Kenyataan }\end{array}$} \\
\hline & $\begin{array}{c}\text { Nilai } \\
\text { Pembobotan }\end{array}$ & $\begin{array}{l}\text { Rata-rata } \\
\text { Harapan }\end{array}$ & $\begin{array}{c}\text { Nilai } \\
\text { Pembobotan }\end{array}$ & $\begin{array}{l}\text { Rata-rata } \\
\text { Persepsi }\end{array}$ & & & \\
\hline $\mathrm{P} 1$ & 401 & 4.42 & 173 & 2.92 & -1.50 & \multirow{4}{*}{17.84} & \multirow{4}{*}{11.07} \\
\hline P2 & 405 & 4.45 & 168 & 2.90 & -1.55 & & \\
\hline P3 & 401 & 4.47 & 165 & 2.56 & -1.91 & & \\
\hline P4 & 396 & 4.50 & 163 & 2.69 & -1.81 & & \\
\hline P5 & 391 & 4.56 & 160 & 2.33 & -2.23 & \multirow{3}{*}{13.89} & \multirow{3}{*}{7.53} \\
\hline P6 & 391 & 4.66 & 160 & 2.61 & -2.05 & & \\
\hline $\mathrm{P} 7$ & 386 & 4.67 & 160 & 2.59 & -2.08 & & \\
\hline
\end{tabular}




\begin{tabular}{clllllll}
\hline P8 & 381 & 4.53 & 152 & 2.70 & -1.83 & & \\
P9 & 376 & 4.59 & 150 & 2.45 & -2.14 & & 12.68 \\
P10 & 372 & 4.52 & 147 & 2.72 & -1.80 & 23.14 & \\
P11 & 367 & 4.62 & 147 & 2.56 & -2.06 & & \\
P12 & 362 & 4.88 & 144 & 2.25 & -2.63 & & \\
P13 & 353 & 4.59 & 138 & 2.74 & -1.85 & & \\
P14 & 353 & 4.74 & 135 & 2.11 & -2.63 & & \\
P15 & 353 & 4.75 & 132 & 2.81 & -1.94 & 23.42 & \\
P16 & 344 & 4.64 & 129 & 2.84 & -1.80 & & \\
P17 & 344 & 4.70 & 126 & 2.70 & -2.00 & & \\
P18 & 312 & 4.39 & 112 & 2.24 & -2.15 & & \\
P19 & 307 & 4.41 & 112 & 3.02 & -1.39 & 13.25 & \\
P20 & 302 & 4.45 & 112 & 2.74 & -1.71 & & \\
\hline
\end{tabular}

Perhitungan rata-rata jawaban antara harapan peserta mengenai pelayanan jasa terhadap persepsi/kenyataan pelayanan yang dirasakan oleh peserta berdasarkan lima dimensi yang terdiri dariTangible, Relibility, Responsivness, Assurance, dan Empathy.Pengelolaan dan praktik sumber daya manusia dalam organisasi memainkan peran penting dalam membangun budaya organisasi dan menciptakan budaya keterbukaan dan inovasi perusahaan di masa yang akan datang (Allui dan Sahni, 2016).

Sumber Daya Manusia telah menjadi sumber yang paling penting dan berharga untuk pendirian, operasi yang sukses dan pembangunan berkelanjutan dari setiap organisasi termasuk organisasi industri.Dan sumber daya manusia adalah satu-satunya sumber daya di antara berbagai sumber daya yang dapat dikembangkan dengan beberapa upaya sistematis dan dengan beberapa sistem.Negara-negara yang menyadari peran penting sumber daya manusia dalam kegiatan pembangunan suatu negara telah melakukan upaya yang tulus dan sistematis untuk mengembangkan sumber daya manusia dan negara-negara tersebut diakui sebagai negara maju dan negara-negara tersebut telah memainkan peran dominan di tingkat global/ dunia (Gonda 2014).Penekanan pada peningkatan kualitas dan relevansi pendidikan dimaksudkan agar sistem pendidikan tetap serasi dan selaras dengan kebutuhan pembangunan, khususnya menghadapi era industrialisasi masyarakat Indonesia. Penekanan ini merupakan salah satu tema pembangunan pendidikan, yang diartikan dengan kesesuaian antara pendidikan dengan kebutuhan pembangunan (Dirwan, 2012).Berikut adalah hasil perhitungan dari nilai ratarata berdasarkan lima dimensi sevqualdapat dilihat pada Tabel 6.

Tabel 6. Nilai Rata-Rata Gap Berdasarkan Lima Dimensi Servqual

\begin{tabular}{ccccc}
\hline No & Dimensi Pertanyaan & $\begin{array}{c}\text { Nilai Harapan } \\
\text { Pelayanan }\end{array}$ & $\begin{array}{c}\text { Nilai Harapan } \\
\text { Persepsi }\end{array}$ & Nilai Gap \\
\hline 1 & Kesigapan & 4.46 & 2.77 & -1.69 \\
2 & Empathy & 4.63 & 2.51 & -2.12 \\
3 & Bukti Fisik & 4.63 & 2.54 & -2.09 \\
4 & Kehandalan & 4.68 & 2.64 & -2.04 \\
5 & Jaminan & 4.42 & 2.67 & -1.75 \\
\hline
\end{tabular}


Analisa tingkat kepuasan peserta digunakan untuk mengidentifikasi dimensi-dimensi dan atribut atau variabel dari setiap dimensi yang membutuhkan perbaikan kualitas. Indeks kepuasan peserta memiliki kategori sangat puas jika memiliki indeks kepuasan lebih besar dari nol dan tidak puas apabila kurang dari nol, sedangkan apabila indeks kepuasan sama dengan nol tergolong puas(Fathoni,2009).

Diagram kartesius merupakan suatu diagram yang dibagi atas empat bagian yang dibatasi oleh dua buah garis yang berpotongan tegak lurus pada titik-titik $(\overline{\bar{X}}, \overline{\bar{Y}})$, dimana $\overline{\bar{X}}$ adalah rata-rata dari rata-rata skor tingkat pelaksanaan persepsi atau kepuasan peserta, $\overline{\bar{Y}}$ adalah rata-rata dari rata-rata skor tingkat kepentingan atau harapan seluruh faktor yang mempengaruhi kepuasan peserta. Untuk nilai rata-rata tingkat kinerja dari Kopertis Wilayah III menggunakan SPSS 17 sebesar 4.56 pada sumbu X dan nilai rata-rata tingkat kepentingan pada sumbu Y sebesar 2.62. Nilai rata-rata dari 20 atribut kualitas pelayanan pada Kopertis Wilayah III dapat dilihat pada Gambar 2.

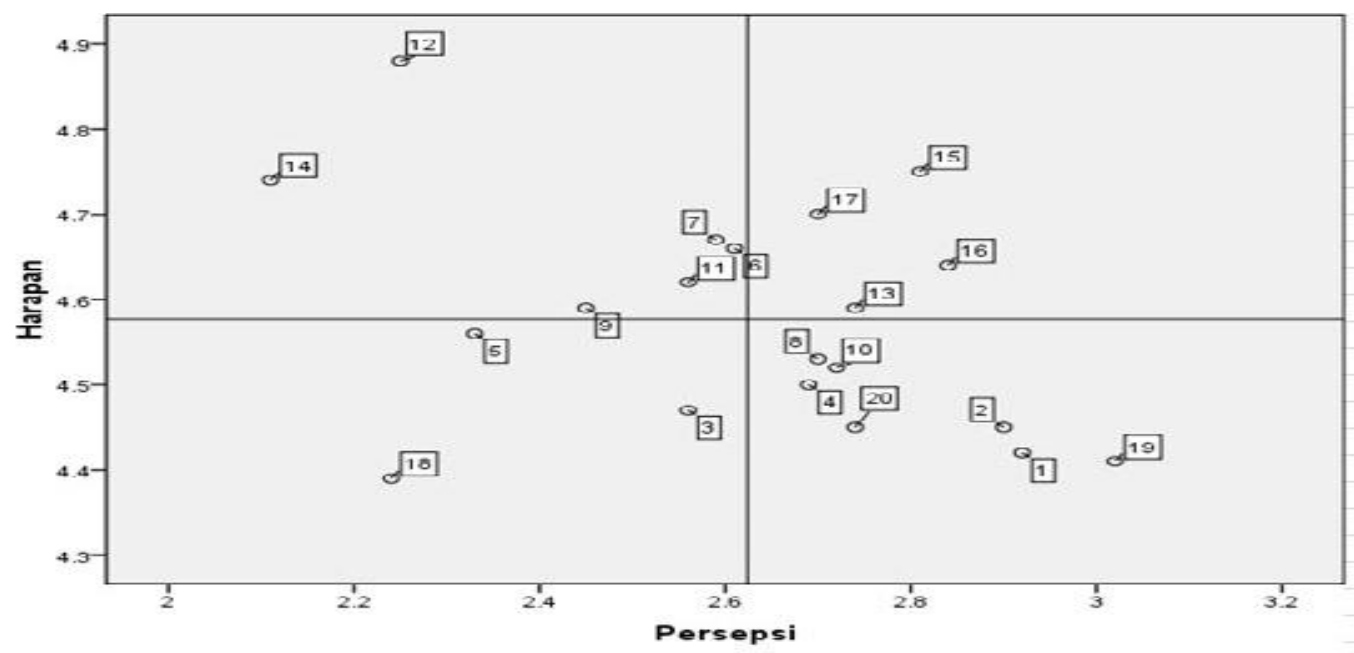

Gambar 2. Diagram Kartesius dengan 4 bagian

Dari hasil pengelompokkan jawaban responden dengan menggunakan diagram kartesius dan telah dibagi ke dalam empat bagian, didapatkan keterangan tentang variabel-variabel yang masuk diantara keempat bagian tersebut, seperti dilihat pada Tabel 7.

Tabel 7. Variabel-Variabel Kelompok Kuadran Kartesius

\begin{tabular}{lll}
\hline Kuadran & \multicolumn{1}{c}{ Variabel Pertanyaan } & \multicolumn{1}{c}{ Keterangan } \\
\hline I & $6,7,9,11,12,14$ & Sangat Penting (Prioritas Utama) \\
II & $13,15,16,17$ & Penting(Pertahankan ) \\
III & $3,5,18$ & Kurang Penting (Prioritas Rendah ) \\
IV & $1,2,4,8,10,19,20$ & Kurang Begitu Penting (Prioritas \\
& & sangat Rendah) \\
\hline
\end{tabular}

Perbaikan pelayanan perlu dilakukan pada atribut-atribut yang kualitas pelayanan dianggap masih kurang berdasarkan hasil penelitian yang telah dilakukan. Untuk melakukan perbaikan pada atribut pelayanan perlu diberikan rekomendasi sesuai dengan apa yang telah didapatkan dari hasil penelitian sehingga perbaikan bisa dilakukan pada 
dimensi dan atribut-atribut secara tepat. Rekomendasi perbaikan diprioritaskan pada atribut yang terletak di kuadran I.

Atribut pertama yang harus dilakukan perbaikan yaitu keramahan, perhatian dan kesopanan staf instruktur beserta Panitia (6). Pihak Kopertis Wilayah III memang seharusnya mempersiapkan staf instruktur/ pemateri dan panitia yang ramah dan cekatan penuh senyum, sehingga peserta merasa nyaman dalam mengikuti pelatihan. Rekomendasi perbaikan untuk jangka pendek yang dapat dilakukan pihak Kopertis Wilayah III yaitu menyediakan instruktur yang kompeten disertai panitia yang berusia muda sehinggapeserta nyaman mengikuti pelatihan, salah satu aspek penting yang menentukan keberhasilan seuah satuan kerja pendidikan adalah aktivitas organisasi secara efisien yang didukung oleh staf administrasi dan pejabat pendidikan yang handal (Muhyadi,2013).

Perbaikan untuk jangka panjangnya bisa merekomendasikan penambahan instruktur, dengan membuka kesempatan sebagai instruktur pelatihan dari Dosen terbaik di wilayah Kopertis Wilayah III, menambah SDM baru yang lebih terlatih dengan perekrutan CPNS baru yang disesuaikan dengan kebutuhan jangka panjang tugas pokok fungsi Kopertis Wilayah III. Salah satu fungsi manajemen surmber daya manusia adalah pelatihan dan pengembangan (training and development) artinya bahwa untuk mendapatkan tenaga kerja pendidikan yang bersumber daya manusia yang baik dan tepat sangat perlu pelatihan dan pengembangan (Satriawan at al., 2016). Tujuan dalam pelatihan dan pengembangan karyawan adalah untuk menghasilkan perilaku dan sikap yang diinginkan, serta keterampilan yang sesuai dan pelayanan yang menyenangkan peserta (Walker, 2008). Atribut kedua yang harus diperbaiki oleh pihak Kopertis Wilayah III yaitu Informasi yang jelas mengenai fasilitas dan peraturan bagi peserta(7). Rekomendasi perbaikan yang dapat dilakukan pihak Kopertis Wilayah III yaitu menjelaskan setiap awal pertemuan mengenai fasilitas dan peraturan bagi peserta, pelayanan yang baik bukan saja diinginkan konsumen karena diperhatikan dan dilayani, tetapi juga keunggulan yang diharapkan oleh perusahaan (Tumpal, 2012). Sistem pendidikan tinggi suatu bangsa adalah 'mesin penciptaan tenaga kerja' bangsa dan sebagai akibatnya bangsa harus merangkul kualitas secara terus menerus untuk dapat berhubungan dengan realitas perubahan saat ini.Dan Dalam dimensi teknologi, sosiologis dan ekonomi yang akan menghasilkan kualitas keterampilan dan kualitas kapasitas manusia sehingga dalam penyesuaian kebutuhan negara-negara berkembang harus menerapkan perbaikan mutu secara terus menerus (Akinyemi dan Abiddin, 2013)

Atribut ketiga yang harus diperbaiki oleh pihak Kopertis Wilayah III adalahfasilitas ruang kelas menunjang kegiatan belajar mengajar(9), perusahaan harusmampu bersaing dalam menunjukkankeunggulan akan produk atau jasa yangdihasilkan dibanding kompetitornya (Yola\&Budianto, 2013). Rekomendasi perbaikan yang dapat dilakukan oleh Kopertis Wilayah III yaitu mempersiapkan media komunikasi dan fasilitas belajar mengajar agar lebih nyaman. Atribut selanjutnya yang harus diperbaiki oleh Kopertis Wilayah IIIsnack dan makanan berkualitas(11), Kualitas mempunyai dampak langsung terhadap prestasi produk atau jasa dan kepuasan konsumen/pelanggan, sehingga semakin puas konsumen/pelanggan maka kualitas pelayanan pada suatu perusahaan akan semakin baik pula atau berkualitas (Firdian at al., 2012). rekomendasi yang dapat dilakukan adalah mempersiakan makanan dan minuman yang berkualitas serta mencukupi. Instruktur dan karyawan selalu berpakaian rapi dan sopan(12),variabel citra perusahaan 
lebih dominan berpengaruh terhadap kepuasan konsumen (Tumpal, 2012). Rangkaian materi yang diberikan bermutu sesuai dengan sasaran program(14), rekomendasi yang dapat diberikan Kopertis Wilayah III adalah mempersiapkan kesiapan panitia dan bahan materi sesuai target pelatihan, salah satu aspek penting dalam menentukan keberhasilan suatu satuan kerja/ instansi/perusahaan adalah terselenggaranya aktivitas organisasi seperti pelatihan yang profesional, efektif dan efisien (Purnama, 2015), salah satu ukuran internasional PT yang berkualitas apabila mencapai predikat World Class University (WCU). Persyaratan WCU tersebut, antara lain: (1) 40 persen pengajar/dosen harus bergelar doktor, (2) publikasi internasional minimal dua paper setiap dosen/staf dalam satu tahun, (3) jumlah mahasiswa pascasarjana minimal 40 persen dari total populasi mahasiswa, (4) anggaran riset minimal US \$ 1,300 per dosen/staf pertahun (5) jumlah mahasiswa asing lebih dari 20 persen, dan (6) Information Communication Technology $10 \mathrm{~KB}$ per mahasiswa. Sebagian besar PT Swasta Indonesia masih sulit mencapai hal tersebut, mengingat terbatasnya sumber daya yang tersedia, seperti sarana prasarana, input, dan kualitas pengelolaan, serta kemampuan dukungan pemerintah yang belum memadai (Dirwan, 2012)

\section{PENUTUP}

Berdasarkan hasil penelitian dapat disimpulkan bahwa kualitas pelayanan di Kopertis Wilayah III belum sesuai dengan harapan peserta. Hal ini ditunjukkan dengan nilai kepuasan peserta pada lima dimensi (Tangible, Relibility, Responsivness, Assurance, Empathy) bernilai negatif yang berarti peserta tidak puas dengan pelayanan yang telah diberikan, sehingga kelima dimensi tersebut perlu dilakukan perbaikan. Berdasarkan ratarata nilai gap dari kelima dimensi diperoleh tingkat kepuasan sebesar -1.908yang berarti peserta merasa tidak atau belum puas. Atribut yang menjadi prioritas utama untuk dilakukan perbaikan dalam kualitas pelayanan di Kopertis Wilayah III yaitu pada atribut keramahan, perhatian dan kesopanan staf instruktur beserta panitia (6), informasi yang jelas mengenai fasilitas dan peraturan bagi peserta (7), fasilitas ruang kelas menunjang kegiatan belajar mengajar (9), snack dan makanan berkualitas(11) dan rangkaian materi yang diberikan bermutu sesuai dengan sasaran program (14). Atribut-atribut yang menjadi prioritas utama untuk dilakukan perbaikan ini merupakan atribut yang berada di kuadran 1 pada diagram kartesius yang harus segera di perbaiki guna perbaikan kualitas Kopertis Wilayah III sebagai peyelenggara kegiatan.

\section{DAFTAR RUJUKAN}

Allui, Sahni . (2016) "Strategic Human Resource Management in Higher Education Institutions: Empirical Evidence from Saudi". Procedia - Social and Behavioral Sciences, 235 (2), $361-371$.

Asmawi,Masyuri. (2011) Metodologi Riset Manajemen Pemasaran, Cetakan II. Malang: UIN-MALIKI PRESS.

Dirwan. (2012) "Perguruan tinggi yang berkualitas merupakan bagian dari konsep kemandirian". Jurnal Mitra Manajemen, 4(2),76-79.

Dirwan. (2014) "Analisis pengaruh budaya organisasi dan komitmen terhadap kinerja dosen perguruan tinggi swasta”. Jurnal Mitra Manajemen, 7(3), 133-141. 
Fathoni. (2009) "Customer service yang baik landasan customer satisfication". Jurnal Usahawan, 12 (1), 23-25.

Firdian, E., Surachman, dan P.B. Santoso. (2012) "Aplikasi Metode Servqual dan Six Sigma dalam menganalisis kualitas layanan PT. PLN (Persero) Unit Pelayanan Jaringan (UPJ) Dinoyo Malang”. Jurnal Ilmu Pengetahuan \& Rekayasa, 13(3), 5061.

Gonda MG. (2014) "Human Resource Development \& Higher Education". Asian Journal Of Management Sciences, 02, 156-159.

Gbenga M. Akinyemi GM, Abiddi NZ. (2013) Quality Administration and Management in Higher Education in Nigeria: Implications for Human Resource Development. International Education Studi, 4(6), 225-235

Henryanto. (2012) "Analisis tingkat kepuasan peserta dilihat dari kualitas pelayanan diklat badan kepegawaian daerah Kabupaten Kepulauan Mentawai”. Jurnal KBP, 2 (1), 1-12.

Muhyadi. (2013) "Kualifikasi dan kompetensi tenaga administrasi sekolah di Daerah Istimewa Yogyakarta". Jurnal Kependidikan, 43(1), 39-50.

Negara, I.D.G.D., A.B. Tjandrarini, dan Sulistiowati. (2014) "Rancang bangun aplikasi analisis pengaruh kualitas pelayanan terhadap kepuasan pelanggan pada Dewi Sinta Hotel and Restaurant". Jurnal Sistem Informatika, 3(1), 27-32.

Purnama, A. (2015) "Sistem pendukung keputusan pemilihan pejabat Kopertis Wilayah III menggunakan metode Analytic Hierarchy Process". Jurnal Penelitian Humaniora, 20 (1), 18-29.

Satriawan, N.N., I.W. Bagin, dan G.P.A. Susan. (2016) "Evaluasi pelaksanaan pelatihan instruksi di lembaga bimbingan belajar Ganesha Operation". Jurnal Manajemen 4 (4), 1-7.

Sekaran, U. (2006) Reserach Methodes for Bussines. Jakarta: Penerbit Salemba.

Sugiyono. (2004) Stastika untuk Penelitian. Bandung: CV Alfabeta.

Sugiyono.(2010) Metode Penelitian Pendidikan. Bandung: Alfabeta.

Suliyanto. (2012) Analisi Data Dalam Aplkasi Pemasaran. Bogor: PT Ghalia Indonesia.

Supranto. (2006) Pengukuran Tingkat Kepuasan Peserta untuk menaikkan Pangsa Pasar. Jakarta: PT Rineka Cipta.

Tjiptono, F. (2005) Pemasaran Jasa. Yogyakarta: Andi.

Tumpal, H. (2012) "Pengaruh citra perusahaan dan kualitas pelayanan terhadap kepuasan konsumen". Management Analysis Journal, 1 (1) 2:1-7.

Walker, J.P. (2008) Restaurant:From Concept To Operation (Fifth Edition). Toronto. John Willey and Sons Inc.

Yola, M., dan D. Budianto. (2013) “Analisis kepuasan konsumen terhadap kualitas pelayanan dan harga produk pada Supermarket dengan menggunakan metodeImportance Performance Analysis (Ipa)". Jurnal Optimasi Sistem Industri, 12 (12), 301-309.

Zeithaml, A.Valarie, LLeonard, Berry, and A. Parasuraman. (1985) "Problem and strategis in services in strategis in services marketing". Journal of Marketing, 52(4), $35-48$.

Zulian, Y. (2002) ManajemenKualitas Produk dan Jasa, Cetakan Kedua. Yogyakarta: Ekonisia. 